\title{
Impact of economic growth on regional development in Jambi Province
}

\author{
M. Iqbal ${ }^{1 *}$; Muhammad Firdaus²; Bambang Juanda²; Dedi Budiman Hakim² \\ 1) Muaro Jambi Regency's Office of Tourism, Youth and Sports, Indonesia \\ ${ }^{2)}$ Economics and Management Faculty, IPB University, Bogor, Indonesia
}

*To whom correspondence should be addressed.E-mail: miqbalhasip@gmail.com

\begin{abstract}
This research work aims to, firstly, analyze the structure of economic growth based on regency/city typology in Jambi Province in 2008-2007, and secondly, to analyze regional development inequality in Jambi Province in 2008-2017. The analytical methods used are cluster analysis and Williamson Index. In this study, regions are grouped based on similar characteristics of economic growth in Regency/City in Jambi Province using cluster analysis in the period 2008 to 2007. The results of the cluster analysis generated three regional groups with different economic characteristics each year. Through Williamson Index it is found that the average value of development inequality in Jambi Province in 2008-2017 is 0.389, indicating that Jambi Province's inequality index is in the intermediate level. The results of panel data regression analysis show that HDI and Expenditure on Goods and Services have a significant effect on economic growth.
\end{abstract}

Keywords: Cluster analysis, Economic growth, Regional inequality

JEL Classification: R10, R11

\section{INTRODUCTION}

Development is a multidimensional process that includes continues changes strived to improve community welfare. One indicator of the success of development at the macro level is economic growth, reflected in changes in Gross Regional Domestic Product (GRDP) in a region (Todaro \& Smith, 2008).

The main objectives of economic development are creating high growth, reducing inequality and the unemployment rate, and eliminating and reducing poverty. Indicators of success in economic development are the achievement of equity, efficient growth and balanced sustainability in economic development.

As one indicator of development, economic growth shows the extent to which economic activities generate additional community income over a given period as measured by the increase per capita GRDP. The higher the income per capita the higher the level of community welfare will be (Todaro \& Smith, 2006). However, the acceleration of rapid economic growth can lead to unequal distribution of income. This is due to the absence of consideration whether economic growth rate is greater or smaller than the rate of population growth or changes in economic structure.

Regional inequality allegedly emerged not only due to the lack of equity in economic development, but also by the differences in the physical characteristics of the region (Sjafrizal, 2014). According to Myrdal (1957), differences in the level of economic progress between regions will result in adverse effects which in this case can cause an imbalance. 
The impact of regional development with economic growth is the existence of different income inequalities between provinces. Jambi Province has a high level of income inequality in Sumatra Island. In 2016, Gini coefficient of Jambi Province was 0.349 and placed the province in the fourth rank in income inequality in Sumatra Island (Figure 1).

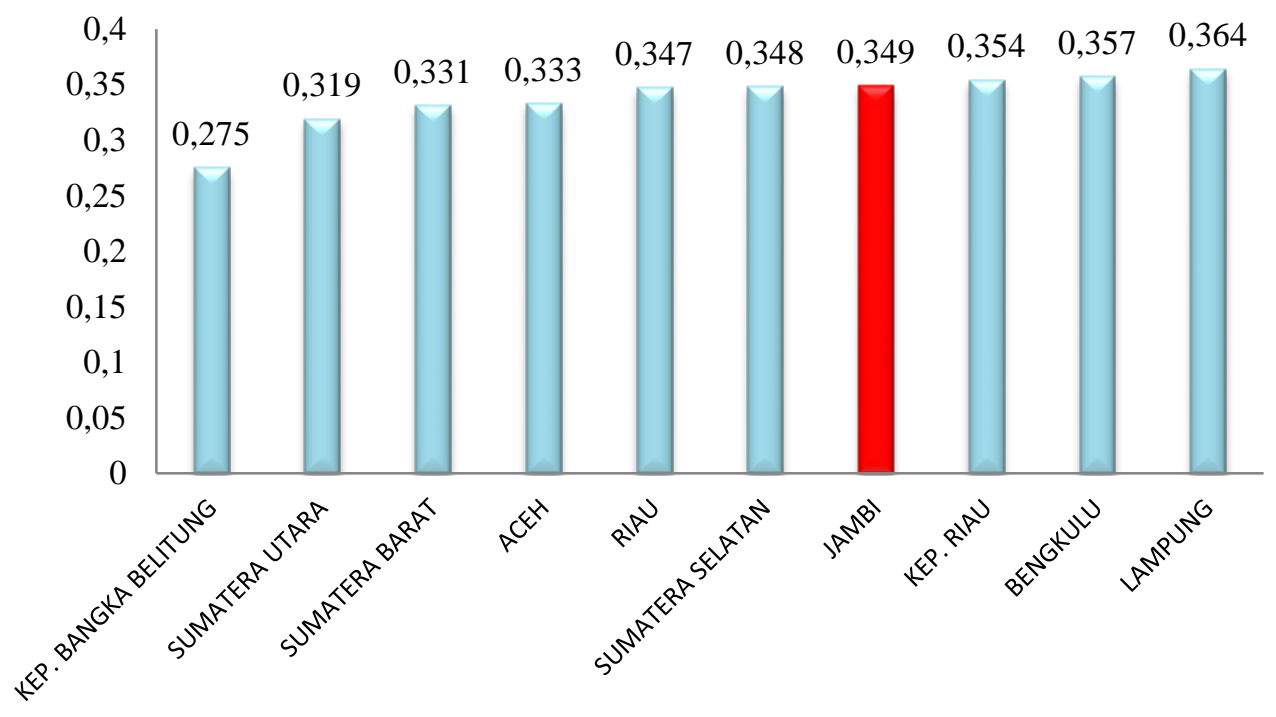

Figure 1. Gini coefficient of provinces in Sumatra Island in 2016

Source: Statistics Indonesia, 2018

Figure 2 show that the coefficient of variation in Jambi Province experienced a fluctuating GRDP change in 2012 - 2017. This indicates the existence of regional disparity in Jambi Province during the time period.

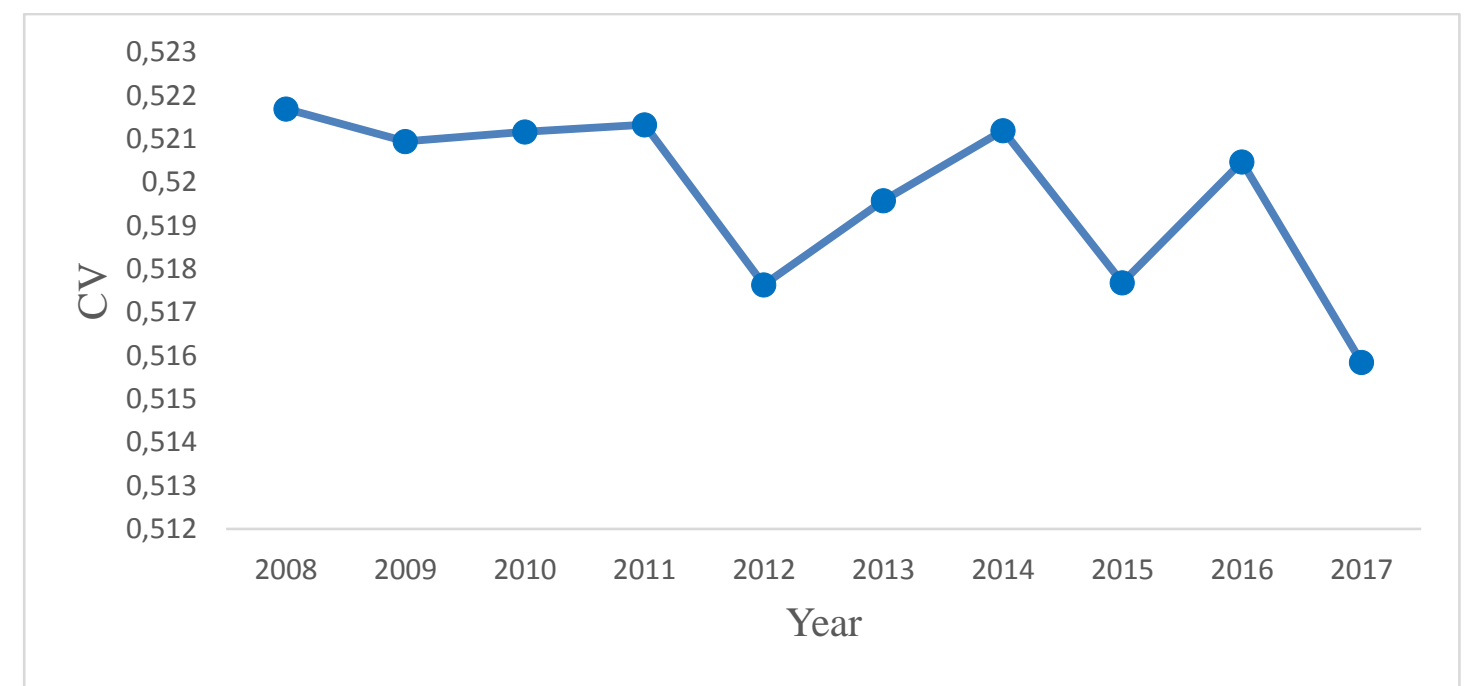

Figure 2. Coefficient of variation (CV) of GRDP in Jambi Province

Based on these facts, this study focuses on three things: (1) the structure of regional economic growth in Jambi Province based on the regional typology, (2) analyzing regional disparity in Jambi Province during 2008-2017, and (3) determining the factors significantly influencing economic growth in Jambi Province. The results of this study are expected to be beneficial for local government in taking policies related to development planning so that the problem of regions inequality can be reduced and addressed properly. 


\section{LITERATURE REVIEW}

\section{Regional development}

Development is creating or managing something that does not exist yet. Rustiadi, Saefulhakim \& Panuju (2007) explained that the concept of development has experienced a paradigm shift in accordance with community development dynamics. The concept of development mentioned is as follows:

1. Shifting from the situation to choose between growth, equity, and sustainability as trade-off choices to become choices in achieving balanced development goals

2. The tendency of approaches to achieving development goals at the macro level becomes approaches at the regional and local level.

3. Shifting assumptions about the dominance of the government into a development approach that encourages community participation in the development processes (planning, implementation, and control).

Development as a series of activities to improve the welfare of the community in various aspects of life, carried out in a planned and sustainable manner by utilizing and taking into account the resources, information, and science and technology advances, as well as looking at global development (Siagian, 2008). Irawan and Suparmoko (1998) stated that development is a process characterized by structural changes in the basis of economic activity or in the economic framework of the community with the process of transformation in the course of time. In general, development is always accompanied by growth, but growth is not always accompanied by development. At the initial level, economic development is followed by growth and vice versa.

Regional development is an integral part of national development carried out by regional autonomy, regulation of national resources, providing opportunities for enhancing democracy and efficient regional performance in the administration of government and community services, to improve the community welfare in the region in an equitable manner. Furthermore Arsyad (1999) and Syafrizal (2008a) stated regional economic development as a process of managing existing resources by local governments and their communities, also creating a partnership pattern among new employment opportunities and stimulating the development of economic activities in the region.

\section{Economic growth}

Kindleberger and Herrick (1977) stated that economic growth is a process of increasing output as a result of increasing the quantity of inputs as well as the efficient in the use of these inputs. They believed that economic growth does not only mean increasing inputs that will result in increased production (increased productivity). Furthermore, in the economic growth theory, the relationship between input and output is interpreted as a technical relationship in which the quantitative formulation sees output as a function of input. Economic growth thus can be stated in an economic growth model with measurable variables and parameters that can be tested statistically for its significance.

Romer (1986) suggests five facts that growth theory must be able to explain: 1) the average growth rate showing no variation with the level of income per capita; 2) the input factor growth rate is not enough to explain the output growth rate; the difference between input and output always presents in growth; 3) trade volume growth positively correlated with output growth; 4) population growth rate negatively correlated with income level; 5) skilled and unskilled workers tend to migrate towards high-income countries. 
In 1987, Robert Solow was awarded the Nobel Prize in economics for his contribution to the theory of economic growth. In developing neoclassical growth model, Solow's research proved to be greatly influenced by the Harrod-Domar approach. The growth model of Solow is seen as a standard model for neoclassical economic growth. Its main framework discusses how economic growth is the impact of changes in quality and quantity of input factors.

The Solow model of growth theory refers to a production function developed by two American authors, Charles Cobb and Paul Douglas, commonly known as the CobbDouglas production function. The model focuses on four variables: output, capital, labor, and knowledge. The function is as follows:

$$
\mathrm{Y}_{(\mathrm{t})}=\mathrm{F}\left(\mathrm{K}_{(\mathrm{t})}, \mathrm{A}_{(\mathrm{t})} \mathrm{L}_{(\mathrm{t})}\right)
$$

Where:

$\mathrm{Y}$ is output

$\mathrm{K}$ is capital

$\mathrm{L}$ is labor

A is knowledge or effective labor

Furthermore, endogenous growth theory has a broader perspective than previous growth theories. In general, previous theories emphasized the importance of the process of capital accumulation in economic growth. In this sense, in order to have a high rate of economic rate a country has to have high rate of investment. Funds to finance investment are obtained from savings. The main key to economic growth therefore lies in the ability of a country to accumulate domestic savings.

The model presents a broader theoretical framework in analyzing the process of economic growth. Factors within the economic system (endogenous) influencing the process of economic growth are identified and analyzed.

Originally referred as new growth theory, the endogenous economic growth theory was born as a response and criticism of the Solow growth. It is the beginning of the revival of a new understanding of the factors determining economic growth in the long run, emerging as a response to the global development driven by technological advances that can improve performance in the production. Such global development could no longer be explained properly by neoclassical theory.

Endogenous growth theory was pioneered by Paul M. Romer in 1986 and Robert Lucas in 1988, initially were dissatisfied with the Solow Model as it was considered insufficient to explain long-run growth. The function in endogenous growth theory: $\mathrm{Y}=$ $\mathrm{AK}$, where $\mathrm{Y}$ is the level of output, A represents influencing factors (technology), and $\mathrm{K}$ is the stock of physical capital and human resources.

\section{Government spending}

In macroeconomic theory, there are three main posts in government spending (Boediono, 1999):

1) Government spending on goods and services

2) Government spending on employee salaries. Employee salary changes affect macroeconomic processes, where changes will affect the level of demand in an indirect manner.

3) Government spending on transfer payments. Transfer payment is not purchase of goods or services by the government in the goods market but rather record payments or direct grants to various community groups, pension payments, interest payments or government loans to the public. 
Sukirno (2000) explained that government expenditure is part of fiscal policy, a government action to regulate the economy by determining the amount of government revenue and expenditure each year in National Budget (Anggaran Pendapatan Belanja Negara/APBN) and in Regional Budget (Anggaran Pendapatan Belanja Daerah/APBD). The purpose of this fiscal policy is to stabilize prices, level of output, and employment opportunities as well as to stimulate or encourage economic growth.

Sukirno (1999) added that the role or intervention of the government is indispensable if the economy is fully regulated by a free market activity, as the economy does not reach full employment levels nor it reaches such stability. It will create a wide fluctuation in economic activities from one period to another and then have serious implications for employment opportunities, unemployment, and price.

\section{GRDP per capita}

GRDP per capita is one of the indicators to see the success of economic development in a region. GRDP is a net value of all final goods and services produced by various economic activities in a region in a period (Sasana, 2006). GRDP is able to give an indication whether a region is capable of managing their natural resources. Potential of their natural resources and other factors of production in a region determine the GRDP of the region. Differences in GRDP value among regions are due to limitations in the supply of those factors. Measurement of GRDP per capita is GRDP at constant price divided by population of a region.

According to Statistics Indonesia (2008), GRDP can be obtained with three approaches: first, the production approach: the total value of all final goods and services produced by various production units in a region/province within a certain period of time; second, the income approach: remunerations received by the factors in the production process in a region in a certain period of time; third, the expenditure approach: the total of all components of the final demand.

\section{Unemployment}

Unemployment is a condition where a person belonging to the labor force who is actively looking for job at a certain level of salary but cannot get the desired job (Sukirno, 2000). Sukirno (2000) stated three kinds of unemployment according to the circumstances: first, frictional unemployment, exists due to people being in the process of leaving one job and looking for another for better or as desired; second, structural unemployment, resulting from structural changes in the economy; and third, conjunctural unemployment, caused by the excessive natural unemployment and as a result of a reduction in aggregate demand.

According to Edwards in Arsyad (1999), in classifying unemployment it is necessary to consider the following dimensions: first, time (many of them want to work longer, e.g., work hours per day, per week or per month); second, work intensity (related to health and food nutrition); and third, productivity (lack of productivity is often caused by lack of complementary resources in work). In this respect, Edwards provides three types of unemployment: first, open unemployment, is a condition in which people are able to work and are willing to work but there is no available jobs suitable for them; second, underemployment, is a condition in which people in full time job but whose productivity is low so the reduction in their working hours has no effect to overall production; third, impaired labor, is a condition in which people may work full time but whose intensity is weak due to malnutrition or illness; and fourth, nonproductive labor, is a condition in which people are able to work productively but cannot produce good results. 
One important factor that determines people's prosperity is the level of income. If the community's income reaches its maximum, then the level of full use of labor can be realized, so that if unemployed it will reduce income and this will reduce the level of welfare and prosperity that they achieve and can lead to poor community welfare (Sukirno, 2004).

One important factor determining the welfare of people is the income rate. If the community's income reaches its maximum then there is full use of labor. If people become unemployed, it will reduce income and eventually reduce the level of welfare and prosperity, thus it can lead to poor community welfare (Sukirno, 2004).

\section{Poverty}

Todaro and Smith (2006) argue that absolute poverty is the number of people who are unable to command sufficient resources to satisfy basic needs. Additionally, Bellinger (2007) argues that poverty has two dimensions: the income dimension and the non-income dimension. Poverty in the income dimension is defined as the low-income family, while in the non-income dimension is characterized by incapability, lack of hope, lack of representation and freedom. Income dimension of poverty is discussed more often as it is easier to measure, and can be divided into relative poverty and absolute poverty.

Poverty is one of the problems arising in development as well as unemployment and inequality, all of which are interrelated. Development is an effort of structural changes intended to increase productivity and create employment opportunities that will ultimately increase the income of the population. However, not all people have the opportunity to be involved in development processes and activities, so there are some who are left behind and stay in the poverty. Special interventions are therefore needed to help those people to be out of poverty.

\section{Human Development Index}

Development has been measured, so far, using GDP and GRDP that are only capable to only indicate economic development. A more comprehensive indicator is therefore needed to not only for economic development but also the development of social and welfare aspects.

Important objectives in calculating HDI as an indicator of human development include: first, using indicators that measure the basic dimensions of human development and expansion of freedom of choice; second, utilizing a number of indicators to keep the measurement simple; third, creating a composite index instead of using a number of basic indices; and fourth, creating a measure including social and economic aspects.

HDI is a basic index composed of the following dimensions: first, long and healthy life, with live expectancy index; second, knowledge, measured by literacy rates and a combination of school participation rates for primary, secondary, and tertiary levels; third, a decent standard living, with indicator of GRDP per capita in the form of Purchasing Power Parity (PPP).

\section{METHODS}

Secondary data are used in this research. Data in the study include data on unemployment, number of population, poverty, HDI, capital expenditure, expenditure on goods and services and GRDP percapita. The data analyzed were obtained from the publications of Statistics Indonesia related to various regional economic indicators in Jambi Province during the period 2008-2017. 
Analysis of regency/city typology was carried out by K-means cluster analysis, performed annually to see the development of economic growth in each regency/city. Indicators for the analysis are GRDP, unemployment, population, poverty, HDI, capital expenditure, expenditures on goods and services, and then the data are mapped.

The stages of $K$-Means Cluster analysis in this study are:

a. Standardization of each variable for each year.

b. Three clusters were determined according to their characteristics.

c. Determining the similarity of the area of the characteristics of economic growth based on the closest distance using the Euclidean distance.

d. Mapping the regencies/cities according to the results of cluster analysis.

To observe the level of regional inequality, Williamson Index is used. In this case the greater the index the greater the level of inequality between regencies/cities in a province. Williamson (1975) formulates the regional inequality index as follows:

$$
V_{w}=\frac{\sqrt{\sum\left(Y_{i}-\tilde{Y}\right)^{2} P_{i}}}{\tilde{Y}}
$$

Where:

$\mathrm{V}_{\mathrm{w}}=$ Williamson Index of Jambi Province

$\mathrm{Y}_{\mathrm{i}}=$ GRDP per capita in 2008-2017 of regencies/cities in the $i$-th

$\tilde{Y}=$ Average GRDP per capita in 2008-2017 of Jambi Province

$\mathrm{P}_{\mathrm{i}}=f i / n$, where $f i$ is the number of regency/city population and $n$ is the total population of the Province

To determine the factors significantly affecting economic growth in Jambi Province in the 2008-2017 periods, panel data regression analysis was performed. Model of panel data regression:

$$
P D R B_{i t}=\beta_{0}+\beta_{1} B M_{i t}+\beta_{2} B B J_{i t}+\beta_{3} P R_{i t}+\beta_{4} K M_{i t}+\beta_{5} I P M_{i t}+\beta_{6} P d d k_{i t}+\varepsilon_{i t}
$$

Where:

PDRB $_{\text {it }}=$ GRDP of regency/city $i$-th in year $t$ (Million Rupiah)

$\mathrm{Pddk}_{\mathrm{it}} \quad=$ number of population of regency/city $i$-th in year $t$ (Person)

$\mathrm{KM}_{\mathrm{it}} \quad=$ poverty rate of regency/city $i$-th in year $t$ (Percent)

$\mathrm{IPM}_{\mathrm{it}} \quad=$ human development index of regency/city $i$-th in year $t$ (Index)

$\mathrm{PR}_{\mathrm{it}} \quad=$ unemployment rate of regency/city $i$-th in year $t$ (Percent)

$\mathrm{BM}_{\mathrm{it}} \quad=$ capital expenditure of regency/city $i$-th in year $t$ (Million Rupiah)

$\mathrm{BBJ}_{\mathrm{it}}=$ expenditure on goods and services of regency/city $i$-th in year $t$ (Million Rupiah)

$\beta_{0} \quad=$ intercept

$\beta_{\mathrm{i}} \quad=$ regression coefficient, with $\mathrm{i}=1,2, \ldots, 6$

$\mathrm{i} \quad=$ regency/city

$\mathrm{t} \quad=$ year between 2018 and 2017

\section{RESULTS AND DISCUSSIONS}

\section{Typology of regencies/cities in Jambi Province}

The results of K-Means cluster analysis of typology of regency/city in Jambi Province with indicators of GRDP per capita, average expenditure per capita, unemployment rate, number of inhabitants/population, poverty rate, HDI, capital expenditure, and expenditure on goods and services obtained three clusters: Cluster 1, 


\section{Cluster 2, and Cluster 3}

Metisen \& Sari (2015) explained that K-Means analysis is non-hierarchical data clustering method that attempts to group data into one group with similar characteristics and one group with different characteristics.

Indicators that differed significantly at the $5 \%$ level based on grouping criteria (high, medium, low) are GRDP, unemployment rate, number of inhabitants, poverty rate, HDI, capital expenditure, and expenditure on goods and services. Those indicators therefore are used to measure the characteristics of economic growth of a region.

Table 1. Characteristics of regional typology of each cluster in 2008

\begin{tabular}{llll}
\hline \multirow{2}{*}{ Indicators } & \multicolumn{3}{c}{ Cluster } \\
\cline { 2 - 4 } & \multicolumn{1}{c}{1} & \multicolumn{1}{c}{3} \\
\hline GRDP & High & Medium & Low \\
Employment rate & High & Medium & Low \\
Number of inhabitants & High & Medium & Low \\
Poverty rate & High & Medium & Low \\
HDI & High & Low & Medium \\
Capital expenditure & Medium & High & Low \\
Expenditure on goods and services & High & Medium & Low \\
\hline
\end{tabular}

In 2008, as Table 1 shows, Cluster 1 is Jambi City; Cluster 2 is Batanghari Regency, Tanjung Jabung Barat, Tanjung Jabung Timur, Bungo, Sarolangun, Merangin, Muaro Jambi and Tebo; while Cluster 3 is Kerinci Regency and Sungai Penuh City.

Changes in the economic growth group occurred every year. As shown in Fig. 3, there are different patterns in regional grouping. On one hand, several regions are consistently in high economic growth group. On the other hand, there are regions that are in low economic growth group each year.

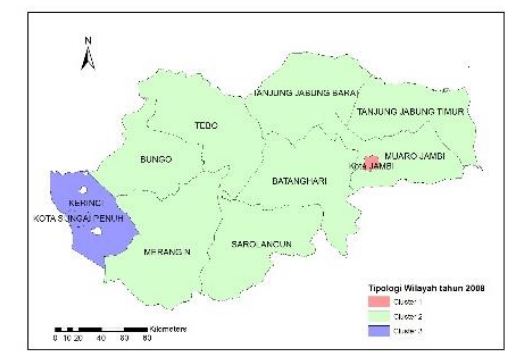

(a) Year 2008

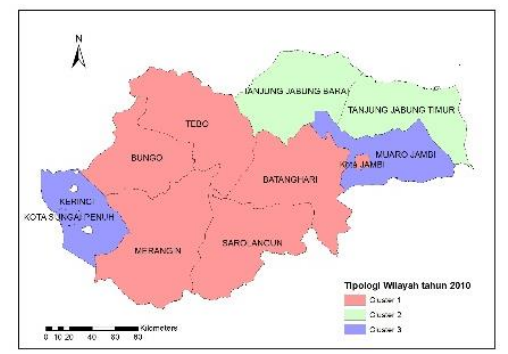

(c) Year 2010

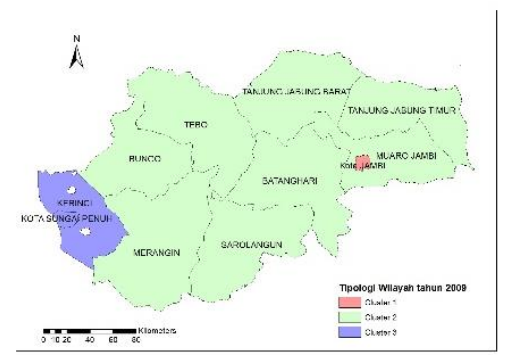

(b) Year 2009

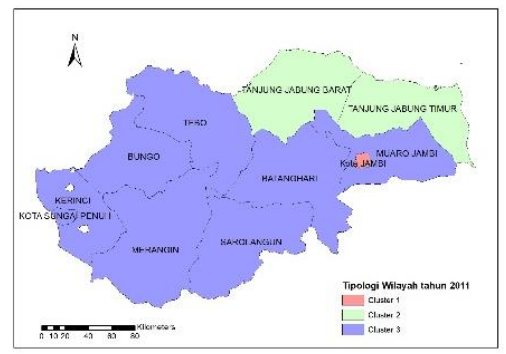

(d) Year 2011 


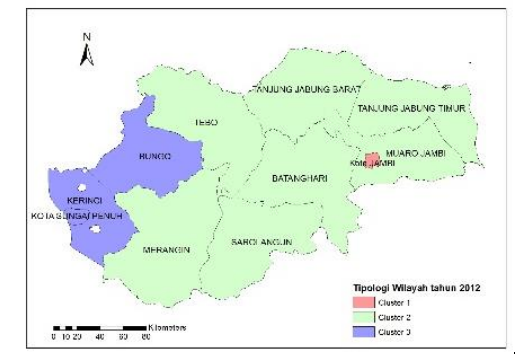

(e) Year 2012

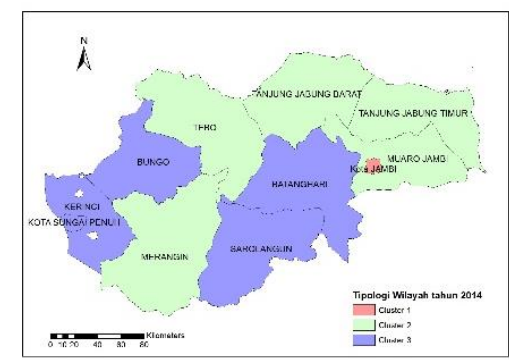

(g) Year 2014

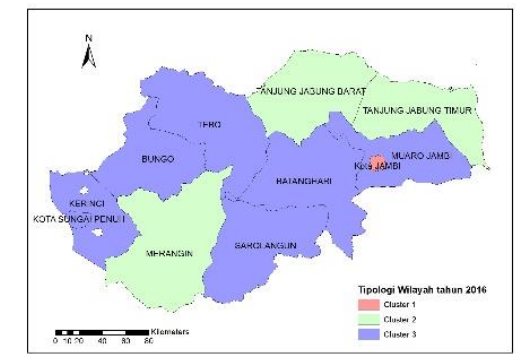

(i) Year 2016

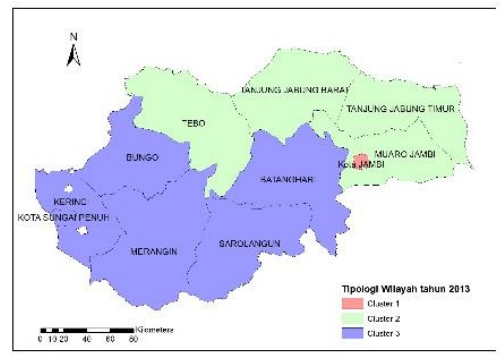

(f) Year 2013

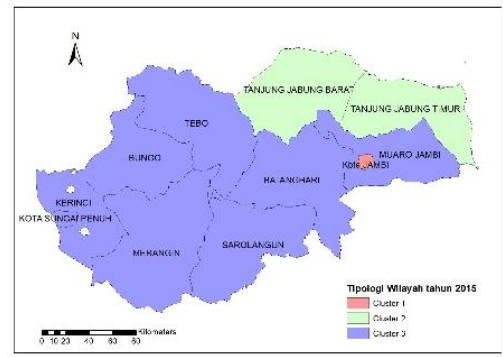

(h) Year 2015

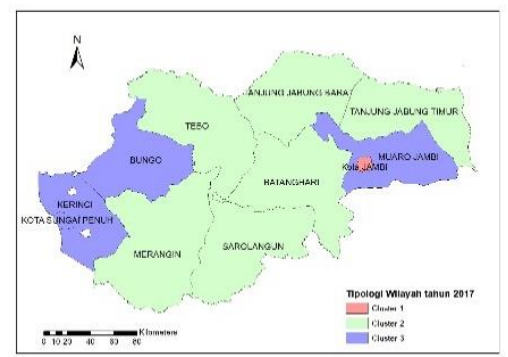

(j) Year 2017

Figure 3. Typology map of regions in Jambi Province in 2008-2017

Between 2009 and 2012 there were significant changes in the characteristics of regional economic growth. In 2010, regions in the high economic growth group were evenly distributed in almost all regencies/cities. However, this condition did not last long as there was a drastic change happened in 2011 that almost all regencies/cities in Jambi Province had low economic growth rate.

There was a change in 2017 that Jambi City consistently was in cluster 1, while cluster 2 consisted of Batanghari, Merangin, Sarolangun, Tanjung Jabung Barat, Tanjung Jabung Timur, and Tebo. Cluster 3 consisted of Muaro Jambi, Bungo, Kerinci, and Sungai Penuh City as shown in Table 3. This is based on the significant indicators as presented in Table 2 .

Table 2. Characteristics of regional typology of each cluster in 2017

\begin{tabular}{llll}
\hline \multirow{2}{*}{ Indicator } & \multicolumn{3}{c}{ Cluster } \\
\cline { 2 - 4 } & & \multicolumn{1}{c}{2} & \multicolumn{1}{c}{3} \\
\hline GRDP & High & Medium & Low \\
Unemployment rate & High & Low & Medium \\
Number of population & High & Medium & Low \\
Poverty rate & Medium & High & Low \\
HDI & High & Low & Medium \\
Capital Expenditure & High & Low & Medium \\
Expenditure on Goods and Services & High & Medium & Low \\
\hline
\end{tabular}


The results on the regional typology show that Jambi City consistently had relatively high economic growth rate (cluster 1). Some regencies/cities in Jambi Province, however, experienced a change in cluster of unstable economic growth (Table $3)$.

Table 3. Typology of regencies/cities in Jambi Province in 2008-2017

\begin{tabular}{|c|c|c|c|}
\hline \multirow[t]{2}{*}{ Year } & \multicolumn{3}{|c|}{ Regency/City Typology } \\
\hline & Cluster 1 & Cluster 2 & Cluster 3 \\
\hline 2008 & Jambi City & $\begin{array}{l}\text { Batanghari, Bungo, Merangin, } \\
\text { Muaro Jambi, Sarolangun, } \\
\text { Tanjung Jabung Barat, Tanjung } \\
\text { Jabung Timur, and Tebo }\end{array}$ & $\begin{array}{l}\text { Kerinci and Sungai } \\
\text { Penuh City }\end{array}$ \\
\hline 2009 & Jambi City & $\begin{array}{l}\text { Batanghari, Bungo, Merangin, } \\
\text { Muaro Jambi, Sarolangun, } \\
\text { Tanjung Jabung Barat, Tanjung } \\
\text { Jabung Timur, and Tebo }\end{array}$ & $\begin{array}{l}\text { Kerinci and Sungai } \\
\text { Penuh City }\end{array}$ \\
\hline 2010 & $\begin{array}{l}\text { Jambi City, } \\
\text { Batanghari, Bungo, } \\
\text { Merangin, } \\
\text { Sarolangun, and } \\
\text { Tebo }\end{array}$ & $\begin{array}{l}\text { Tanjung Jabung Barat, Tanjung } \\
\text { Jabung Timur }\end{array}$ & $\begin{array}{l}\text { Kerinci, Muaro Jambi, } \\
\text { and Sungai Penuh City }\end{array}$ \\
\hline 2011 & Jambi City & $\begin{array}{l}\text { Tanjung Jabung Barat, Tanjung } \\
\text { Jabung Timur, }\end{array}$ & $\begin{array}{l}\text { Kerinci, Muaro Jambi, } \\
\text { Batanghari, Bungo, } \\
\text { Merangin, Sarolangun, } \\
\text { Tebo and Sungai Penuh } \\
\text { City }\end{array}$ \\
\hline 2012 & Jambi City & $\begin{array}{l}\text { Tanjung Jabung Barat, Tanjung } \\
\text { Jabung Timur, Muaro Jambi, } \\
\text { Tebo, Batanghari, Merangin, } \\
\text { Sarolangun }\end{array}$ & $\begin{array}{l}\text { Bungo, Kerinci, and } \\
\text { Sungai Penuh City }\end{array}$ \\
\hline 2013 & Jambi City & $\begin{array}{l}\text { Tanjung Jabung Barat, Tanjung } \\
\text { Jabung Timur, Muaro Jambi, } \\
\text { Tebo }\end{array}$ & $\begin{array}{l}\text { Batanghari, Merangin, } \\
\text { Sarolangun, Kerinci, } \\
\text { Bungo, and Sungai } \\
\text { Penuh City }\end{array}$ \\
\hline 2014 & Jambi City & $\begin{array}{l}\text { Tanjung Jabung Barat, Tanjung } \\
\text { Jabung Timur, Muaro Jambi, } \\
\text { Tebo, Merangin }\end{array}$ & $\begin{array}{l}\text { Batanghari, Bungo, } \\
\text { Sarolangun, Kerinci, } \\
\text { and Sungai Penuh City }\end{array}$ \\
\hline 2015 & Jambi City & $\begin{array}{l}\text { Tanjung Jabung Barat, Tanjung } \\
\text { Jabung Timur }\end{array}$ & $\begin{array}{l}\text { Muaro Jambi, Tebo, } \\
\text { Merangin, Batanghari, } \\
\text { Bungo, Sarolangun, } \\
\text { Kerinci, and Sungai } \\
\text { Penuh City }\end{array}$ \\
\hline 2016 & Jambi City & $\begin{array}{l}\text { Tanjung Jabung Barat, Tanjung } \\
\text { Jabung Timur, Merangin }\end{array}$ & $\begin{array}{l}\text { Muaro Jambi, Tebo, } \\
\text { Batanghari, Bungo, } \\
\text { Sarolangun, Kerinci, } \\
\text { and Sungai Penuh City }\end{array}$ \\
\hline 2017 & Jambi City & $\begin{array}{l}\text { Tanjung Jabung Barat, Tanjung } \\
\text { Jabung Timur, Merangin, } \\
\text { Batanghari, Tebo, Sarolangun }\end{array}$ & $\begin{array}{l}\text { Muaro Jambi, Bungo, } \\
\text { Kerinci and Sungai } \\
\text { Penuh City }\end{array}$ \\
\hline
\end{tabular}




\section{Regional development inequality analysis}

The results of the Williamson inequality index analysis in Jambi Province indicate that, in general, there was a fluctuation every year of inequality level during 2008-2017 with an average of 0.389 or at the level of intermediate of development inequality. This finding is in line with the study of Darzal (2016) that the development level based on Williamson index in Jambi Province in 2009-2014 is fluctuating.

In Jambi Province, inequality existed due to the differences in the ability of each region and also from various factors (natural resources, human resources, and population distribution) implicating on gross value added (GVA) in the economy among regions. The increase in economic growth is accompanied by rising inequality because the majority of the population is farmers. In this case the government must prioritize improving the quality of human resources in agriculture sector in order to achieve high agricultural productivity and efficiency and improve the economy (Mauliddiyah, 2014).

The occurrence of regional inequality is caused by differences in the endowment factor. Inequality that causes different levels of development in different regions and regions refers to the relative standard of living of the whole community. This difference causes a gap or welfare gap in various regions (Sukirno, 1976). The highest level of regional inequality in 2012 was 0.402 and the lowest in 2008 was 0.361 . (Figure 4)

Regional inequality is caused by differences in the endowment factor. The inequality refers to the relative standard of living of the whole community. The difference becomes a welfare gap in the regions (Sukirno, 1976). The highest level of regional inequality was recorded in 2012 of 0.402 and the lowest was in 2008 of 0.361 (Figure 4).

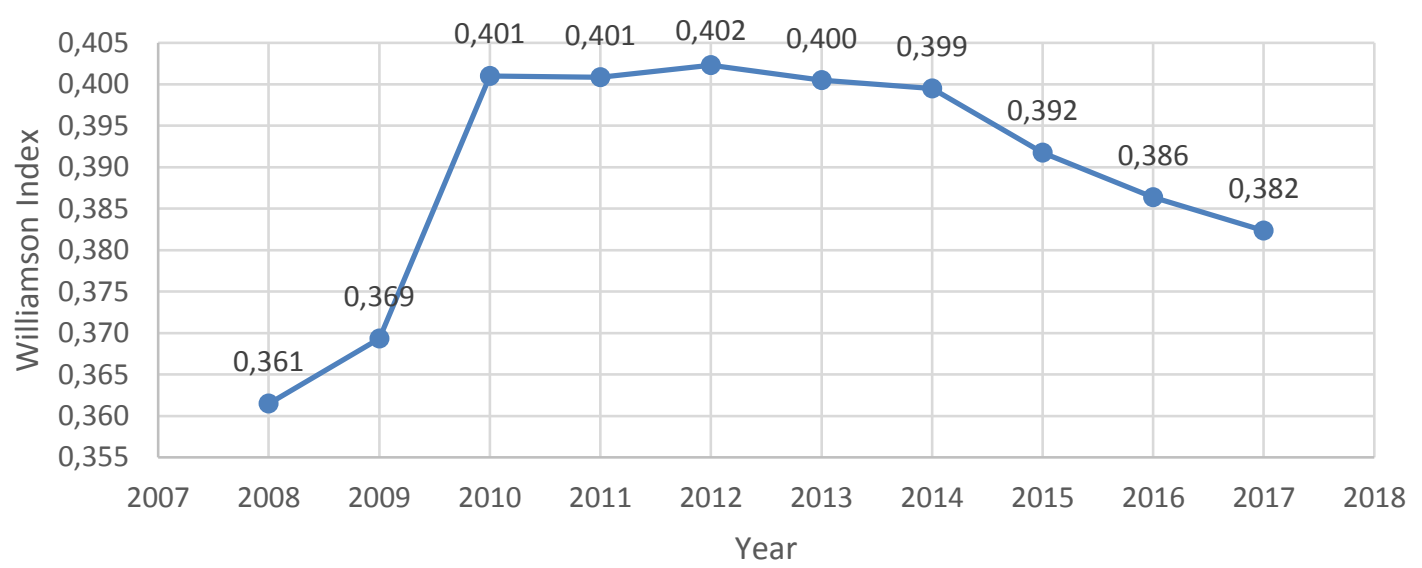

Figure 4. Regional inequality Williamson Index of Jambi Province in 2008-2017

Inequality in regional development is a universal phenomenon in all countries regardless of the size and level of development. Effort to reduce inequality among regions is increasing cooperation between regions so that there will be a balanced economic rise (Bahasoan, Hakim, Nurmalina, \& Putri, 2019). According to Anwar (2005), it is necessary to give attention regarding the inequality in development both in terms of inter-community groups and spatial aspects, which is a problem of uneven regional development.

Jhingan (2010) explained that economic growth is an increase in the long-term capability of a country to provide more economic goods to its people. A country is able to provide various types of economic goods to its people with long-term economic 
growth. Rapid development, however, prioritizes accelerated economic growth and it can affect development disparities between regions.

\section{Factors affecting economic growth}

The selection of panel data regression model is an analysis stage to determine the best estimation method between Common Effect, Fixed Effect, and Random Effect. Chow test aims to find out which model choice is better to use between Common Effect and Fixed Effect.

Table 4 shows the $p$-value of cross-section Chi-square is $0.000<\alpha=0.05$, so H0 is rejected, indicating that Fixed Effect model is better to use than Common Effect model.

Table 4. Significant Test of Fixed Effect through Chow Test

\begin{tabular}{llll}
\hline \hline Effects Test & Statistic & d.f. & Prob. \\
\hline \hline Cross-section F & 275.927146 & $(10,49)$ & 0.0000 \\
Cross-section Chi-square & 267.201273 & 10 & 0.0000 \\
\hline \hline
\end{tabular}

Table 4 shows the $p$-value of cross-section Chi-square is $0.000<\alpha=0.05$, so H0 is rejected, indicating that Fixed Effect model is better to use than Common Effect model.

Hausman test is carried out to find out the better model to use between Fixed Effect and Random Effect. Table 5 shows that the $p$-value is $0.0203<\alpha=0.05$ which means that $\mathrm{H} 0$ is rejected, so Fixed Effect model is the better model to use.

Table 5. Significant test of random effect through Hausman Test

\begin{tabular}{lccl}
\hline Test Summary & Chi-Sq. Statistic & Chi-Sq. d.f. & Prob. \\
\hline Cross-section random & 14.994956 & 6 & 0.0203 \\
\hline
\end{tabular}

Based on the result of estimation of Chow test and Hausman test on three panel data regression models (pool Least Square, Fixed Effect, and Random Effect), it is obtained that the best model is Fixed Effect model. The results of regression of Capital Expenditure (BM), Expenditures on Goods and Services (BBJ), Unemployment (PR), Poverty (KM), HDI, and Population (Pddk) to the GRDP of regencies/cities in Jambi Province are shown in Table 6.

Table 6. Coefficients of factors affecting GRDP

\begin{tabular}{lccc}
\hline \multirow{2}{*}{ Independent Variable } & \multicolumn{2}{c}{ Dependent Variable (ln_PDRB) } & \multirow{2}{*}{ Note } \\
\cline { 2 - 3 } & \multicolumn{2}{c}{ Coefficient } & p-value \\
\hline Intercept & -21.252 & 0.000 & $* *$ \\
ln_BM & 0.026 & 0.250 & $\mathrm{~ns}$ \\
ln_BBJ & 0.057 & 0.059 & $*$ \\
ln_PR & 0.002 & 0.868 & $\mathrm{~ns}$ \\
ln_KM & -0.045 & 0.539 & $\mathrm{~ns}$ \\
ln_IPM & 7.603 & 0.000 & $* *$ \\
ln_Pddk & 0.072 & 0.851 & $\mathrm{~ns}$ \\
\hline F-statistic & 827.735 & 0.000 & \\
\hline Adj. R-squared & 0.99 \\
\hline
\end{tabular}

Note: **: Significant at 5\% level, * : Significant at 10\% level, ns: not significant 
The results obtained in the model indicate that HDI has a significant impact on the GRDP of regencies/cities in Jambi Province at a 5\% level. The coefficient value of HDI is 7.603 and is indicating that every $1 \%$ increase in HDI will impact on the increase of GRDP by 7.603 percent with the assumption that other variables are unchanged. This finding is in line with study of Brata (2002), Khodabakshi (2011), Aryanto \& Handaka (2017), Akhsan (2018) and Firmansyah \& Soejoto (2016) which concluded that good quality of human development supports economic development and vice versa, but contradict with Mukarramah, Yolanda, Zulkarnain (2019).

Expenditure on Goods and Services (BBJ) has a significant influence on GRDP of regencies/cities in Jambi Province at a $10 \%$ level. The coefficient value of BBJ is 0.057 , indicating that every $1 \%$ increase in BBJ will raise GRDP by 0.057 percent with the assumption that other variables are unchanged.

In the other hand, capital expenditure (BM), unemployment (PR), number of population (ppdk) and poverty (KM) have no significant impact on GRDP of regencies/cities in Jambi Province. This finding is in line with study of Handaka (2017), Yunus \& Amirullah (2019), but contradict with Hakim (2015), Utami \& Indrajaya (2019)

These findings are in line with Jambi Province's condition that at the same time there are concentration of economic growth and increased poverty in the same region. It tells us that poverty and unemployment do not have a significant effect on GRDP of Jambi Province. Based on the 2017 data, the highest GRDP was owned by Jambi City, Tanjung Jabung Barat, and Tanjung Jabung Timur, but at the same time, the percentage of poverty was also the highest in regions including those three areas. Tanjung Jabung Timur had the highest percentage of poverty of 12 percent, followed with Tanjung Jabung Barat with 11 percent, Batanghari of 10 percent, Merangin of 9 percent, and both Sarolangun and Jambi City had 8 percent in the poverty rate, respectively. Furthermore, Fajri (2016) added that capital expenditure did not have a significant influence in increasing the economic growth of provinces in Sumatra. Policies relating to the allocation of capital expenditure are not appropriate so they have not been able to encourage regional economic growth.

$\mathrm{R}$-Square value of the research model is 0.99 , indicating that $99 \%$ of the imbalance/diversity of GRDP in regencies/cities in Jambi Province can be explained by the independent variables in the model while the rest is explained by other variables outside the model.

\section{CONCLUSIONS AND RECOMMENDATIONS}

\section{Conclusions}

Based on the regional typology with cluster analysis, Jambi City is the only region that has the highest economic growth rate compared to others in Jambi Province. Muaro Jambi and Bungo are classified as regions with unstable economic growth. In 2008, those regencies were in the moderate economic growth group but they joined the low economic growth group in 2017.

The results of Williamson Index analysis in Jambi Province during the 2008-2017 provide evidence that there was an inequality in development with the average value of 0.389, indicating that Jambi Province was in the intermediate level of development inequality. This is due to differences in various factors such as population distribution, 
natural resources, and human resources that have implications for gross value added (GVA) in the economy among regions in Jambi Province.

The results of panel data regression with Fixed Effect Model indicated that Expenditure on Goods and Services (BBJ) and HDI have a significant impact on GRDP of regencies/cities in Jambi Province.

\section{Recommendations}

At the macro level, local government intervention in rising regional economic growth rate can be done through improving factors affecting GRDP and economic growth rate namely Expenditure on Goods and Services (BBJ) and Human Development Index (HDI). Local government should formulate policies that reduce regional development inequality in Jambi Province, especially in regions classified in the low economic growth cluster and regions with high level of inequality. Some of the policies include improving the quality of education, health, decent living standards, and infrastructure.

\section{REFERENCES}

Akhsan. (2018). Pengaruh Index Pembangunan Manusia Terhadap Pertumbuhan Ekonomi Daerah Di Kabupaten Enrekang. Economis: Jurnal Ekonomi dan Bisnis, $1(3), 49-55$

Anwar, A. (2005). Ketimpangan Pembangunan Wilayah Dan Pedesaan: Tinjauan Kritis. Bogor: Crestpent Press.

Ardila, R. (2012). Analisis Pengembangan Pusat Pertumbuhan Ekonomi di Kabupaten Banjarnegara. Economics Development Analysis Journal (EDAJ), 1(2): 1-9.

Arsyad, L. (1999). Pengantar Perencanaan dan Pembangunan Ekonomi Daerah. Yogyakarta: BPFE-UGM

Aryanto, W \& Handaka, R.D. (2017). Analisis Pengaruh Belanja Modal, Indeks Pembangunan Manusia, dan Tenaga Kerja terserap terhadap Pertumbuhan Ekonomi Kabupaten/kota di Indonesia. Jurnal Akuntansi Manajerial, 2(2), 52-63.

Bahasoan, H., Hakim, D.B, Nurmalina, R., \& Putri, E.I.K. (2019). Typology and inequality between island clusters and development areas in Maluku Province. Jurnal Perspektif Pembiayaan Dan Pembangunan Daerah, 7(2), 203 214.

Bellinger, W.K. (2007). The Economcs Analysis of Public Policy. Oxon: Routledge

Boediono. (1999). Teori Pertumbuhan Ekonomi, Seri Sinopsis Pengantar Ilmu Ekonomi No.4, Edisi Pertama. Yogyakarta: BPFE-UGM

BPS. (2008-2017). Provinsi Jambi Dalam Angka 2008-2017. Jambi: BPS Provinsi Jambi.

Brata, A.G. (2002). Pembangunan Manusia dan Kinerja Ekonomi Regional di Indonesia. Jurnal Ekonomi Pembangunan, 7 (2), 113-122.

Darzal. (2016). Analisis Disparitas Pendapatan dan Faktor-Faktor yang Mempengaruhinya di Provinsi Jambi. Jurnal Perspektif Pembiayaan dan Pembangunan Daerah, 4(2),132-142

Fajri, A. (2012). Pengaruh Belanja Modal terhadap Pertumbuhan Ekonomi provinsiprovinsi di Sumatera. Jurnal Perspektif Ekonomi dan Pembangunan Daerah. 5(1), 29-35 
Firmansyah, M.A. \& Soejoto, A. (2016). Pengaruh Indeks Pembangunan Manusia dan Tingkat Pengangguran Terhadap Pertumbuhan Ekonomi Kabupaten Bojonegoro. Jurnal Pendidikan Ekonomi, 4(3), 1 - 6

Hakim, L. (2015). Pengaruh Belanja Modal Terhadap Pertumbuhan Ekonomi (Studi Kasus Kabupaten dan Kota di Pulau Jawa dan Bali). Jurnal Ilmiah Mahasiswa FEB Universitas Brawijaya, 3(1)

Harlik, Amir, A. \& Hardiani. (2013). Faktor-faktor yang mempengaruhi kemiskinan dan Pengangguran di Kota Jambi. Jurnal Perspektif Pembiayaan dan Pembangunan Daerah. 1(2),109-120

Irawan \& Suparmoko. (2003). Ekonomika Pembangunan. Edisi keenam. Yogyakarta: BPFE. UGM.

Jhingan, M.L. (2000). Ekonomi pembangunan dan perencanaan. Jakarta: Raja Grafindo Persada.

Kindleberger, C.P. \& Herrick, B.H. (1983). Economic Development. 4th ed. New York: McGraw-Hill.

Khodabakhshi, A. (2011). Relationship between GDP and Human Development Indices in India. International Journal of Trade, Economics and Finance, 2(3), 251-253.

Maulidiyah, A. (2014). Analisis Disparitas Regional dan Pertumbuhan Ekonomi (Studi Kasus di Kota Batu Tahun 2002-2012). Jurnal Ekonomi dan Studi Pembangunan (JESP), 6(2), 156 - 163

Metisen BM, \& Sari H.L. (2015). Analisis Clustering Menggunakan Metode K-Meas Dalam Pengelompokan Penjualan Produk pada swalayan Fadhila. Jurnal Media Infotama, 11(2), 110-118

Mukarramah, Yolanda, C., \& Zulkarnain, M. (2019). Analisis Pengaruh Belanja Modal dan IPM Terhadap Pertumbuhan Ekonomi dan Kemiskinan di Kabupaten Aceh Timur. Jurnal Samudra Ekonomika, 3(2), 105-117.

Myrdal, G. (1957). Rich Lands And Poor: The Road To World Property. New York: Harper and Row

Romer, P.M. (1986). Increasing Return and Long Growth, Journal of Political Economy, 94 (5), 1002-1037.

Rustiadi, E., Saefulhakim, S., \& Panuju, D.R. (2009). Perencanaan Dan Pengembangan Wilayah. Bogor: Crestpent Press.

Siagian, P.S. (2008). Administrasi Pembangunan, Konsep, Dimensi dan Strateginya. Jakarta: Bumi Aksara

Sjafrizal. (2008). Perencanaan Pembangunan Ekonomi Daerah. Prisma, 12, 15-24.

Sjafrizal. (2008a). Ekonomi Regional, Teori dan Aplikasi. Padang: Baduose Media

Sjafrizal. (2014). Perencanaan Pembangunan Daerah Dalam Era Otonomi. Jakarta: PT Rajagrafindo Persada.

Sukirno, S. (1976). Beberapa Aspek Dalam Persoalan Pembangunan. Jakarta: LP3ES.

Sukirno, S. (1999). Ekonomi Pembangunan. Jakarta: LPFE-UI

Todaro M.P. \& Smith, S.C. (2006). Pembangunan Ekonomi di Dunia Ketiga. Jakarta: Erlangga

Utami, D.N. \& Indrajaya, I.G.B. (2019). Pengaruh PAD dan Belanja Modal terhadap Pertumbuhan Ekonomi dan Kesejahteraan Masyarakat di Provinsi Bali. E-Jurnal EP UNUD, 8(10), 2195 - 2225 
Yunus, S. \& Amirullah. (2019). Pengaruh Belanja Modal terhadap Pertumbuhan Ekonomi (Studi pada Kabupaten-Kabupaten di Provinsi Aceh). Jurnal Samudra Ekonomika, 3(2), 186-193. 